\title{
Morphology and distribution of Encyonema angustecapitatum KRAMMER species complex (Bacillariophyceae) with description of four new species from São Paulo, southeast Brazil
}

\author{
Gisele C. Marquardt ${ }^{1 *}$, Simone Wengrat ${ }^{1}$, Denise C. Bicudo ${ }^{1}$, Carlos E. Wetzel ${ }^{2}$, \\ Luc ECTOR $^{2} \&$ Carlos E. DE M. BICUDO ${ }^{1}$
}

\author{
${ }^{1}$ Instituto de Botânica, Department of Ecology, Av. Miguel Estéfano 3687, 04301-012, São Paulo, SP, Brazil; \\ *Corresponding author e-mail: giselecmarquardt@gmail.com \\ ${ }^{2}$ Luxembourg Institute of Science and Technology (LIST), Environmental Research et Innovation (ERIN) De- \\ partment, 41 rue du Brill, L-4422 Belvaux, Grand-duchy of Luxembourg
}

\begin{abstract}
Type material of Encyonema angustecapitatum KRAMMER was investigated to establish the identity of several Brazilian Encyonema populations. In order to elucidate the differences and similarities of that species complex, morphological features under light and scanning electron microscopy were detailed. Notes on their distribution were also discussed. MDS analysis distinguished four Encyonema species presently described as new to science: Encyonema acquapurae sp. nov., Encyonema sparsistriatum sp. nov., Encyonema tenue sp. nov. and Encyonema paradisiacum sp. nov. The four new species can be separated on the basis of a combination of the following morphological features: valve outline, axial area, valve length, valve width, length to width ratio, number of striae in $10 \mu \mathrm{m}$ and number of areolae in $10 \mu \mathrm{m}$. Regarding ecological preferences, all four species were mainly found in oligotrophic and oligo-mesotrophic environments.
\end{abstract}

Key words: morphology, multidimensional scaling procedure (MDS), new species, taxonomy, type material, ultrastructure

\section{INTRODUCTION}

The biraphid diatom genus Encyonema KüTzING (Cymbellales) has over 400 described taxa (FourTANIER \& KoCiOLeK 2011); 17 species and 5 varieties were recorded for Brazil (EskinAZI-LEÇA et al. 2015), and five new taxa were recently described (TREMARIN et al. 2011; Silva et al. 2013a, b; Silva \& Souza 2015; Marquardt et al. 2016). Encyonema species are very common in freshwater benthic communities with low electrolyte content (Round et al. 1990; KRAMMER 1997b).

Encyonema was separated from Cymbella C. AgARDH by Krammer (1997a, b) after an extensive revision of the cymbelloid taxa, including 50 new species and some material from Brazil (Tapajós River, Brazilian Amazon). The genus was proposed to designate dorsiventral individual specimens with distal raphe ends curved to the ventral margin, opposed to all Cymbella species. Encyonema angustecapitatum KrAMMER and E. ponteanum Krammer were described in the above contribution, both after the study of Venezuelan material. In general, this 'species complex' shows a more or less similar morphology characterized by having (i) strongly dorsiventral asymmetrical valve outline; (ii) small capitate ends; and (iii) narrow ventral axial area with central area absent (KRAMMER 1997b).

Several populations of the E. angustecapitatum complex were found in samples from São Paulo state (southeast Brazil) during a project that aimed at identifying the São Paulo state algal flora (BIOTA-FAPESP Program) and also during a paleolimnological investigation that aimed at contributing towards the diatom biodiversity and autecology for the establishment of environmental scenarios and policy maker's information (AcquaSed Project).

Analysis of E. angustecapitatum and E. ponteanum type material revealed the existence of four distinct Encyonema taxa that were misidentified at first sight. Such inadequate identifications improved the uncertainty of those species distribution besides affecting the accuracy of the diagnostic tools relying on diatom taxonomy and ecology. Such species are presently described as new to science using both light (LM) and scanning electron microscopy (SEM). Notes on their ecological preferences and distribution are 
also included. The description of the four new species contributes to the knowledge of their diversity, geographic distribution and morphology.

\section{Material ANd Methods}

The original gathering from Rio Caroni (Venezuela) containing both Encyonema angustecapitatum and E. ponteanum, i.e. sample 1114B in KRAMMER collection kept at the Hustedt Diatom Study Centre of the Alfred Wegner Institute, Bremerhaven (BRM), corresponding to the slide 1099C, was observed. The material was prepared only for SEM analysis since there was not enough raw material available. Morphological measurements of $E$. ponteanum were based on KRAMMER's (1997b) light microscopy photos.

Altogether, four sample units containing E. angustecapitatum complex representatives collected from semilentic and lentic environments and plankton, periphyton and surface sediments from different localities in the São Paulo state (southeast Brazil) were analyzed under LM and SEM.

Plankton samples were obtained with a $20 \mu \mathrm{m}$ mesh nylon plankton net and a VAN DoRN water sampler (VAN DORN 1956). Periphytic material was scrapped from stones and macrophytes (floating and/or submerged). Surface sediments (first superficial $2 \mathrm{~cm}$ ) were collected using a gravity core (UWITEC). A list of all samples studied and their characteristics is given in Table 1. Also, their water chemical and physical data are compiled in Table 2.

Permanent slides were prepared using BatTARBEE et al. (2001) technique, with heated peroxide hydrogen $\left(\mathrm{H}_{2} \mathrm{O}_{2}\right.$ $37 \%)$ to remove the organic matter. The reaction was further completed by addition of hydrochloric acid ( $\mathrm{HCl} \mathrm{37 \% )}$ and following centrifugation cycles $(1500 \mathrm{rpm})$ to rinse the acid excess. A permanent slide from the organic-free material was mounted using Naphrax (R.I. = 1.74). The diatom community was investigated using a Zeiss Axio Imager A2 light microscope $(\mathrm{LM})$ at $1000 \times$ magnification, equipped with $\mathrm{Di}$ fferential Interference Contrast (DIC) and an AxioCamMR5 digital camera. For the scanning electron microscopy (SEM) analysis, a subsample of the cleaned material was dried out on filters mounted on aluminium stubs and coated with platinum using a BAL-TEC MED 020 Modular High Vacuum Coating System for $30 \mathrm{~s}$ at $100 \mathrm{~mA}$. An ultra-high-resolution analytical field emission (FE) scanning electron microscope Hitachi SU-70 (Hitachi High-Technologies Corporation, Tokyo, Japan) operated at $5 \mathrm{kV}$ and $10 \mathrm{~mm}$ distance was used for the analysis. SEM images were taken using the lower (SE-L) detector signal. Photomicrographs were digitally manipulated and plates containing light and scanning electron microscopy images prepared using the CorelDRAW Graphics Suite X7

Morphological terminology and comparisons between species were mostly based on $\operatorname{KrAMMER}(1997 \mathrm{a}, \mathrm{b})$ and Round et al. (1990).

The species complex morphological differences were valued using Bray-Curtis similarity multidimensional scaling procedure (MDS) performed with $\mathrm{R}$ version 3.1.2 ( Development Core Team 2015) using the 'vegan' package (OKSANEN et al. 2016) and an analysis of similarity (NPMANOVA) was performed between the values of resulting groups in the MDS using the Euclidean distance measure. A scatterplot matrix $(n=63)$ was achieved using the pac-

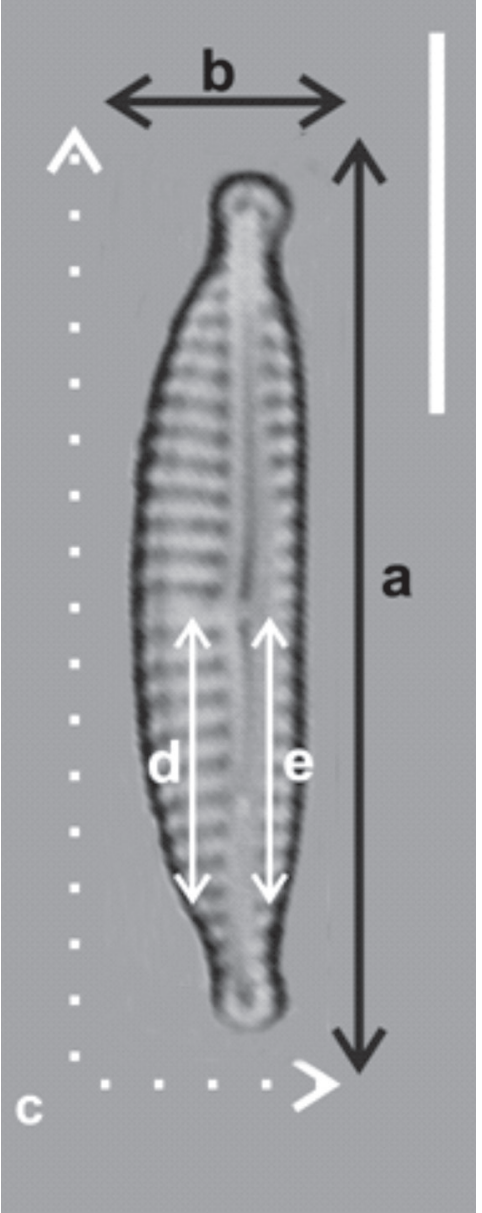

Fig. 1. Morphological differences considered in MDS procedure: (a) valve length; (b) valve width; (c) length to width ratio; (d) number of dorsal striae in $10 \mu \mathrm{m}$; (e) number of ventral striae in $10 \mu \mathrm{m}$.

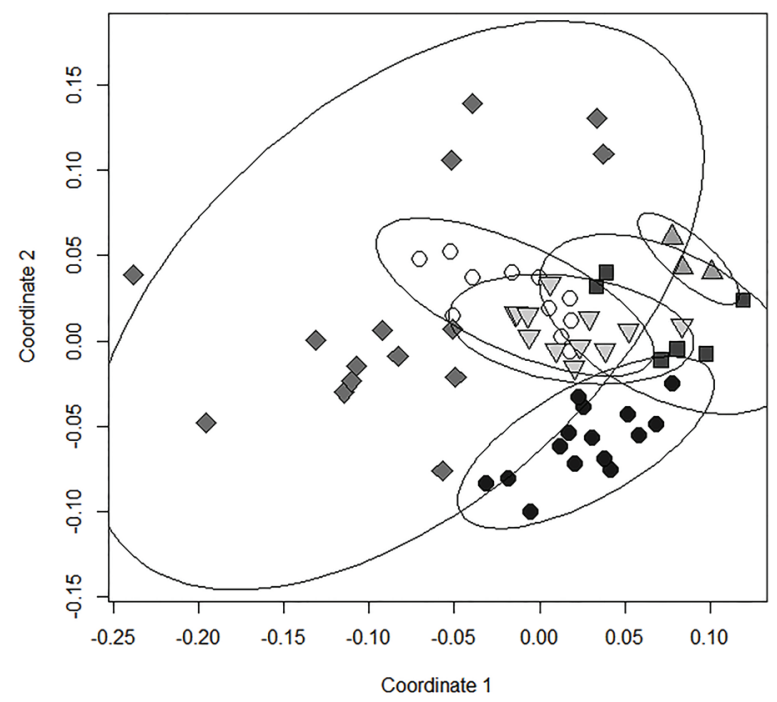

Fig. 2. Multidimensional scaling procedure (MDS) plot based on Bray-Curtis similarities between E. angustecapitatum species complex in this study and 4 species distinguished by cluster analysis (symbols). Legend symbols: (filled circle) E. acquapurae; (white circle) E. tenue; (inverted triangle) E. sparsistriatum; (diamond) E. paradisiacum; (square) E. angustecapitatum; (triangle) E. ponteanum. 
Table 1. Data from sampling sites of Encyonema angustecapitatum complex, state of São Paulo, Brazil, habitat and the material number at the Herbarium of the Institute of Botany (SP).

\begin{tabular}{llllll}
\hline Sample & $\begin{array}{l}\text { Geographical } \\
\text { coordinate }\end{array}$ & $\begin{array}{l}\text { Year of } \\
\text { collection }\end{array}$ & Municipality & Site description & Habitat \\
\hline SP188327 & - & 1989 & Casa Branca & Marsh & Plankton \\
SP401589 & $223^{\circ} 47^{\prime} 1.62^{\prime \prime S}$, & 2009 & $\begin{array}{l}\text { São Paulo, Diadema, } \\
\text { Ribeirão Pires, Santo } \\
46^{\circ} 26^{\prime} 11.28^{\prime \prime}\end{array}$ & $\begin{array}{l}\text { Billings Reservoir, Rio } \\
\text { Pequeno branch, upstream } \\
\text { region }\end{array}$ & Benthos \\
SP468841 & $\begin{array}{l}23^{\circ} 39^{\prime} 31.8^{\prime \prime S}, \\
45^{\circ} 49^{\prime} 23.22^{\prime \prime}\end{array}$ & 2010 & Salesópolis & Ribeirão do Campo Reservoir & Benthos \\
\hline
\end{tabular}

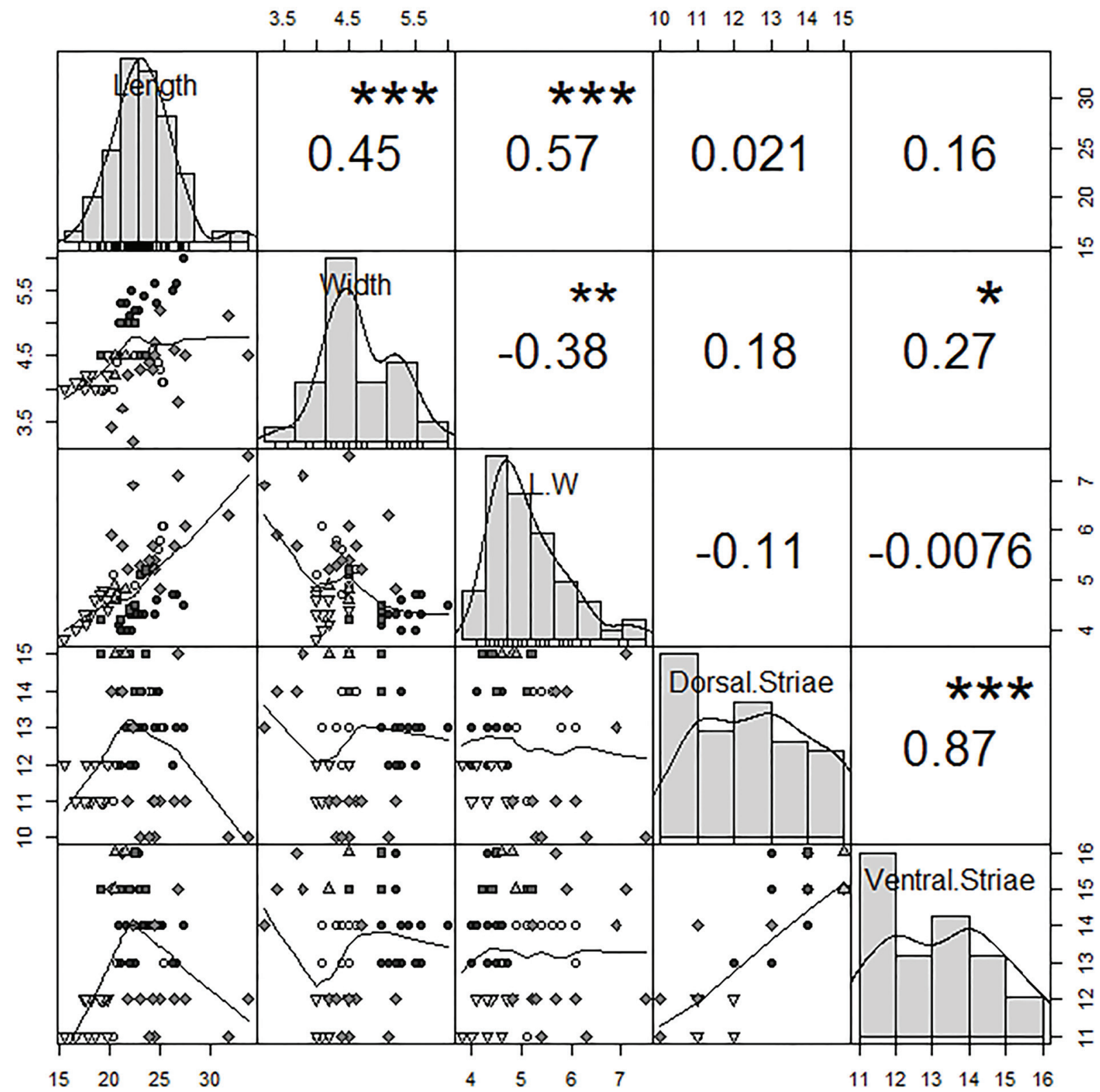

Fig. 3. Scatterplot matrix of measurements of new Encyonema species. Variation in the valve length, width, striae in $10 \mu \mathrm{m}$ and length to width ratio (L:W). Distribution of each variable is shown on the diagonal. Legend: (filled circle) E. acquapurae; (square) E. tenue; (diamond) $E$. sparsistriatum; (triangle) E. paradisiacum; (inverted triangle) E. angustecapitatum; (white circle) E. ponteanum. Lower panel: the bivariate scatter plots with a fitted line are displayed. Upper panel: the value of the correlation plus the significance level as stars. Each significance level is associated to a symbol: p-values $(0,0.001,0.01,0.05,0.1,1)<=>$ symbols (“***”, “**”, “*”, “.”, “”). 
Table 2. Available ecological data from sampling sites of Encyonema angustecapitatum complex (mean values from the water column), State of São Paulo, Brazil. Cond. (conductivity), $\mathrm{N}^{-\mathrm{NH}_{4}}$ (ammonium), Temp. (temperature), TN (total nitrogen), TP (total phosphorus).

\begin{tabular}{lcccccc}
\hline Sample & $\begin{array}{c}\text { Temp. } \\
\left({ }^{\circ} \mathbf{C}\right)\end{array}$ & $\mathbf{p H}$ & $\begin{array}{c}\text { Cond. } \\
\left(\boldsymbol{\mu S . c m} \mathbf{S}^{-1}\right)\end{array}$ & $\begin{array}{c}\mathbf{N}^{-N_{H}} \\
\left(\boldsymbol{\mu g . l ^ { - 1 }}\right)\end{array}$ & $\begin{array}{c}\text { TN } \\
\left(\boldsymbol{\mu g . . ^ { - 1 }}\right)\end{array}$ & $\begin{array}{c}\text { TP } \\
\left(\boldsymbol{\mu g . l ^ { - 1 }}\right)\end{array}$ \\
\hline SP401589 & 17.8 & 5.1 & 31.9 & 137.8 & 632.9 & $<4.0$ \\
SP468841 & 16.8 & 5.5 & - & 24.1 & 362.0 & $<4.0$ \\
\hline
\end{tabular}

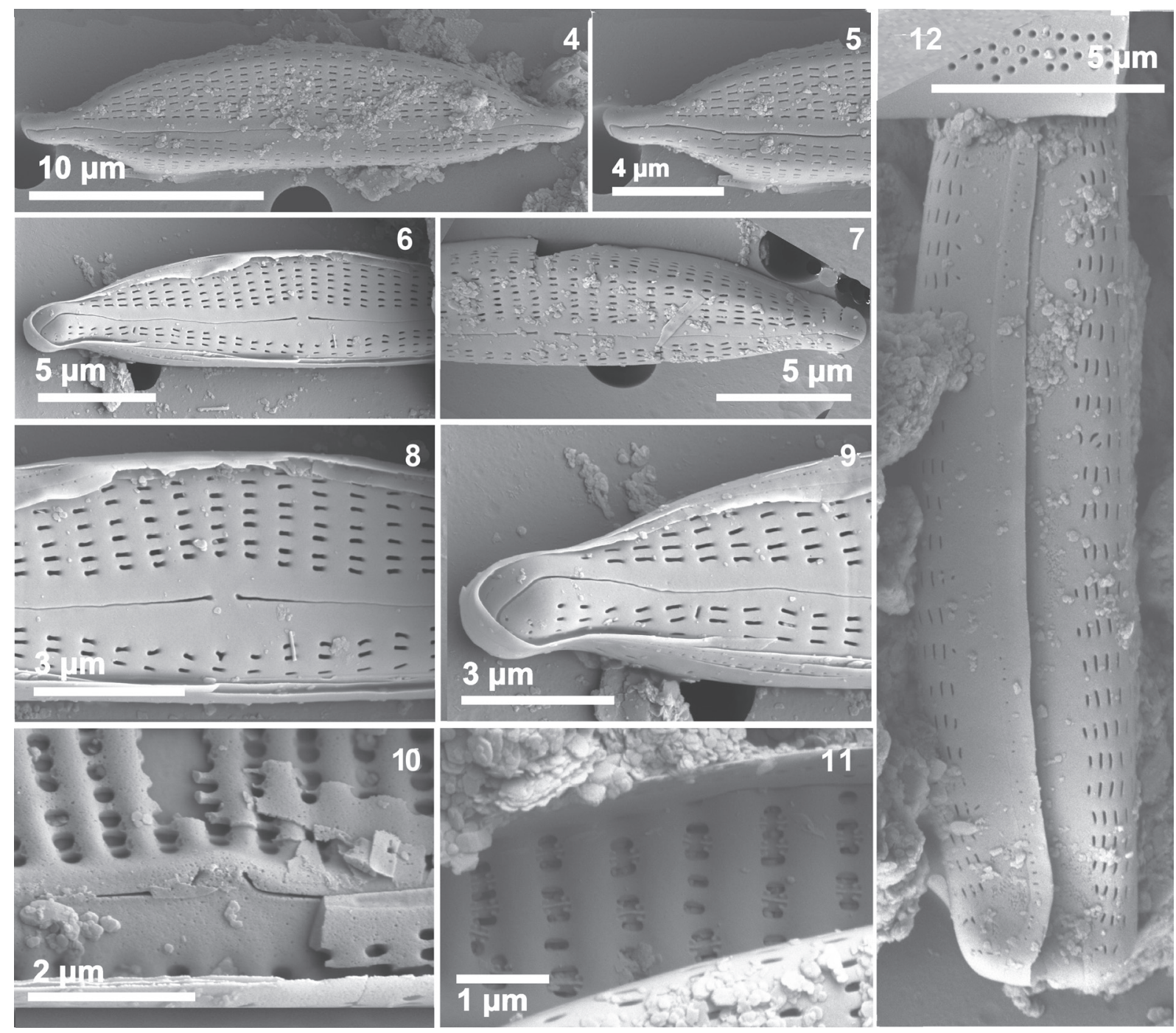

Figs 4-12. Type material of Encyonema angustecapitatum, scanning electron micrographs, all pictures taken from the holotype population (1114B): (4-9) SEM external views of entire valve showing the raphe and striae structure; (10, 11) SEM internal detail of areolae and raphe, note the areolae with struts providing structural support to the foramen; (11) SEM internal detail of central area with intermissio; (12) SEM external view of girdle bands. Note the line of small pores.

kage 'Performance Analytics' (Peterson et al. 2014). The following features were taken into consideration: (1) valve length (apical axis) and width (transapical axis), (2) length to width ratio, (3) number of dorsal striae in $10 \mu \mathrm{m}$, and (4) number of ventral striae in $10 \mu \mathrm{m}$ (Fig. 2). Differences in morphometric data were examined using Kruskal-Wallis non-parametric "Rcmdr" test and the package version 2.1-7
(Fox 2005, 2007).

Holotype permanent slides, as well as the raw and cleaned samples were deposited at Herbário Científico do Estado "Maria Eneyda P. Kauffmann Fidalgo" (SP), São Paulo State Department of Environment, Brazil. Isotypes were deposited at BR, the Botanic Garden Meise, Belgium. 


\section{Results AND Discussion}

KRAMMER type material

Encyonema angustecapitatum KRAMMER (Figs 4-12) Type: Venezuela. Caroni river-Fährstellen. Leg. Rumrich, April 1, 1990.

Holotype: 1099C IOK, housed at the Hustedt collection BRM(!). Corresponding to sample 1114B.

Scanning electron microscopy (SEM): External raphe fissure slightly undulate (Figs 4, 6, 7). Proximal raphe end almost straight, the enlarged proximal endings slightly curved to the dorsal side (Figs 4, 6-8). Raphe distal ends are first dorsally bent, than strongly hooked to the ventral side ending onto the mantle (Figs 4-7, 9). Axial area is narrow, linear (Figs 4, 6, 7). Striae uniseriate composed by lineolae (Figs 4-12), numbering $36-38$ in $10 \mu \mathrm{m}$. Internally, struts provide structural support to the foramen, whose opening bears three spines at each side (Figs 10, 11). Internally, the raphe fissure is interrupted by an intermissio (Fig. 10).

Distribution and ecology: Encyonema angustecapitatum and E. ponteanum are sporadically mentioned, suggestive of an underestimation of their real distribution. Register of E. angustecapitatum is in a specific webpage about diatoms, that includes illustration and information on its geographic distribution in the United States (Phycology Section, Patrick Center for Environmental Research, Academy of Natural Sciences of Drexel University. Encyonema angustecapitatum (NADED 110034). https:// diatom.ansp.org/taxaservice/ShowTaxon1.ashx?naded_id=110034. Accessed 26 Oct 2016).

For South America, the species was reported by Metzeltin \& Lange-Bertalot (1998) in a survey of material collected in the Tapajós River (Brazil). RuMRICH et al. (2000) documented E. angustecapitatum from the San Lucior pond (Colombia) and Vouilloud et al. (2010) from the Colombian Amazon material (Porvenir River, Amazonas). The latter was collected in a phytoplankton sample of a river with $\mathrm{pH} 6.3$, conductivity of $10 \mu \mathrm{S} . \mathrm{cm}^{-1}$, Secchi depth of $62 \mathrm{~cm}$ and a temperature of $27.5^{\circ} \mathrm{C}$. Then, Montoya-Moreno et al. (2013) through a bibliographical revision to recognize freshwater diatom species present in Colombia, registered the species for the sites already mentioned previously (Porvenir River, San Lucior pond) and also for Frontino moorland. However, no illustration nor description were provided.

Precisely for Brazil, only three E. angustecapitatum published records were found. SouzA \& OLIVEIRA (2007) reported the species from an epilithic diatom floristic survey of the Paraná River Basin (Goiás State), but no illustrations or descriptions were provided. MARQUARDT et al. (2010) registered the species in a study of periphytic diatoms in the Rio das Pedras, located in Guarapuava (Paraná State). Nevertheless, this taxon differs from the type material for absence of shoulders especially on its ventral margin. Finally, MarquardT \& Bicudo (2014) reported E. angustecapitatum during the floristic survey of the Cymbellales (Bacillariophyceae) from the Parque Estadual das Fontes do Ipiranga (PEFI), São Paulo city, southeast Brazil. Although a brief description and illustration of the above specimens were available, clear differences can be noticed when it is compared to the type material, such as the presence of a lanceolate, ventral axial area and the absence of well-defined shoulders.

The only register about E. ponteanum is, however, its original description in KRAMMER (1997b).

\section{Formal descriptions of the new species}

Encyonema acquapurae Wengrat, Marquardt et C.E. Wetzel sp. nov. (Figs 13-26)

Light microscopy (LM) (Figs 13-21): Valves strongly dorsiventral. Dorsal margin broadly arched. Ventral margin linear. Apices narrow, subcapitate to capitate, sometimes slightly deflected to the ventral margins. Shoulders clearly developed. Length 20.8-27.4 $\mu \mathrm{m}$. Width 5.0-6.0 $\mu \mathrm{m}$. Length to width ratio 4.0-4.7. Axial area narrow, linear, wider on the ventral margin. Central area absent. Raphe filiform, lateral. Proximal fissures weakly expanded, curved to dorsal margin. Raphe distal ends strongly deflected to the ventral margin. Striae parallel to slightly radiate at the ends. Dorsal striae $13-14$ in $10 \mu \mathrm{m}$, ventral striae $13-16$ in $10 \mu \mathrm{m}$. Indistinct areolae. Stigmoid absent.

Scanning electron microscopy (SEM) (Figs 22-26): External raphe fissure slightly undulate (Figs 22, 23). Proximal end of raphe almost straight, the enlarged proximal endings slightly curved to the dorsal side (Figs 22, 23, 25). Raphe distal ends are first dorsally bent, then strongly hooked to the ventral side ending onto the mantle (Figs 22, 23, 26). Axial area is narrow, linear, and wider on the ventral margin (Figs 22, 23). Striae uniseriate composed by apically-elongate areolae (Figs 22, 23, 25, 26), numbering ca. 36 in $10 \mu \mathrm{m}$. Internally, raphe fissure is interrupted by an intermissio (Fig. 24). Raphe distal endings terminating on welldeveloped helictoglossae (Fig. 24).

Etymology: From Latin 'acquapura', meaning pure water, in reference to the very clear waters of the Rio Pequeno branch, in which the species was collected. Type locality: Brazil. São Paulo, Billings Reservoir, Rio Pequeno branch, sample SP401589 (2347'1.62"S, $\left.46^{\circ} 26^{\prime} 11.28^{\prime \prime} \mathrm{W}\right)$, leg. S. Wengrat et D. Bicudo, coll. date $06 / 08 / 2009$.

Holotype: SP401589 (Herbário Científico do Estado "Maria Eneyda P. Kauffmann Fidalgo", São Paulo, Brazil, depicted in Figs 13-21).

Isotype (here designated): BR-4422 (Botanic Garden, Meise, Belgium). 
Taxonomic remarks: This species is very similar to $E$. angustecapitatum and they can be misidentified at first sight, especially under light microscopy (LM). The type material here investigated (Figs 4-12) and which was illustrated by KRAMMER (1997b, pl. 130: figs 8-15) clearly show the differences between the two species. Thus, E. acquapurae can be discriminated by having (i) more radiate dorsal striae, (ii) wider axial area on ventral side, (iii) greater measurements (length: 20.8-27.4 $\mu \mathrm{m}$ and width: 5.0-6.0 $\mu \mathrm{m}$ ), and (iv) smaller length to width ratio (4.0-4.7).

This species is to be compared to E. pankowii Lange-Bertalot et Krammer in Krammer. Although their measurements overlap, the latter has less striae and areolae in $10 \mu \mathrm{m}$ (Table 3), so that they appear somewhat coarse when they are seen in LM. Encyonema acquapurae is distinguished from E. ponteanum by its largest dimensions and smaller length to width ratio (Table 3). Another similar species, E. gaeumannii (F. Meister) Krammer is smaller $(4-5 \mu \mathrm{m})$ and has comparatively more striae (15-18) and more areolae in $10 \mu \mathrm{m}(38-42)$, as well as more protracted ends. Furthermore, it shows very narrow axial area and larger apices (Table 3). In addition, all these species show a parallel striae pattern whereas E. acquapurae has a radiated one.

Encyonema acquapurae is also similar to E. $k a$ baniense Rodionova et Pomazkina in Pomazkina \& RoDIONOVA (2014). Although no LM images of the latter species are available, differences regarding its areolae pattern (rounded and internally supported by struts) may be useful in separating both taxa.

Ecology: Encyonema acquapurae material was common in samples collected from plankton and surface sediments of the Billings reservoir Rio Pequeno branch (relative abundance $\leq 2 \%$ ). The water is oligo-mesotrophic with low nutrient concentrations (Table 2). The new species was collected associated with Brachysira brebissonii R. Ross, Encyonopsis sanctipaulensis Wengrat et al., Eunotia veneris KützING and Encyonema sparsistriatum sp. nov.

Encyonema tenue Marquardt, Wengrat et C.E. WeTZEL sp. nov. (Figs 27-38)

Light microscopy (LM) (Figs 27-35): Valves strongly dorsiventral. Dorsal margin arched. Ventral margin slightly arched to linear, with a slight indentation near the median area. Apices narrow, capitate, sometimes slightly deflected to the ventral margin. Shoulders clearly developed. Length 20.4-25.3 $\mu \mathrm{m}$. Width $4.0-4.5 \mu \mathrm{m}$. Length to width ratio 4.6-6.1. Axial area narrow, linear, wider on the ventral margin. Central area absent, sometimes with shorter and spaced striae on dorsal side (Figs 32-34). Raphe filiform, lateral. Proximal fissures weakly expanded, slightly curved to dorsal margin. Raphe distal ends strongly deflected to the ventral margin. Striae parallel to slightly radiate at the ends. Dorsal striae $11-14$ in $10 \mu \mathrm{m}$, ventral striae 11-14 in $10 \mu \mathrm{m}$. Indistinct areolae. Stigmoid absent. Scanning electron microscopy (SEM) (Figs 36-38): External raphe fissure slightly undulate (Figs 36, 38). Proximal end of raphe almost straight, enlarged, slightly curved to the dorsal side (Figs 36, 38). Raphe distal ends are first dorsally bent, and then strongly hooked to the ventral side ending onto the mantle (Figs 36, 38). Axial area is narrow, linear (Figs 36, 38), slightly wider to the ventral side. Striae are composed of rounded to lineolate areolae (Figs 36, 38), numbering 35-40 in 10 $\mu \mathrm{m}$. Internal striae are composed of rounded, lineolate and unequal areolae (Fig. 37). Internally, the raphe fissure is interrupted by an intermissio (Fig. 37). Raphe distal ends terminating in well-developed helictoglossae (Fig. 37).

Etymology: Specific epithet refers to the lesser valve width when compared to E. acquapurae.

Type locality: Brazil, São Paulo, Casa Branca, sample SP188327, leg. A.A.J. Castro et C.E.M. Bicudo, coll. date $17 / 10 / 1989$.

Holotype: SP188327 (Herbário Científico do Estado "Maria Eneyda P. Kauffmann Fidalgo", São Paulo, Brazil, depicted in Figs 27-35).

Isotype (here designated): BR-4468 (Botanic Garden, Meise, Belgium).

Taxonomic remarks: The new species was recorded as E. angustecapitatum in MARquARDT \& Bicudo (2014). However, ultrastructural analysis showed that the Casa Branca specimens have rounded areolae, whereas in the type material are lineolate. Spaced dorsal striae at median region were not observed in E. angustecapitatum. All other features usually overlap.

Encyonema pankowii has less striae (10-11) and areolae (18-20) in a $10 \mu \mathrm{m}$ interval, wider valvar width (5.5-6.5 $\mu \mathrm{m})$ and length to width ratio (4.4) (Table 3).

Ecology: Encyonema tenue was collected from a marsh (Casa Branca city, São Paulo State) with relative abundance $\leq 2 \%$. The new collected species was associated with Encyonopsis schubartii (HustedT) KRAMMER, Kurtkrammeria frequentis (KRAMMER) BAHLS and Gomphonema sp. There is no information about the local water nutrients.

Encyonema sparsistriatum MARQUARDT, WENGRAT et C.E. Wetzel sp. nov. (Figs 39-51)

Light microscopy (LM) (Figs39-47): Valves strongly dorsiventral. Dorsal margin arched. Ventral margin slightly convex to linear. Apices narrow, rostrate to capitate. Shoulders poorly developed. Length 15.5$21.5 \mu \mathrm{m}$. Width 4.0-4.7 $\mu \mathrm{m}$. Length to width ratio 4.0-4.8. Axial area narrow, linear, wider on the ventral margin. Central area absent. Raphe filiform, lateral. Proximal fissures weakly expanded, curved to dorsal margin. Raphe distal ends strongly deflected to 


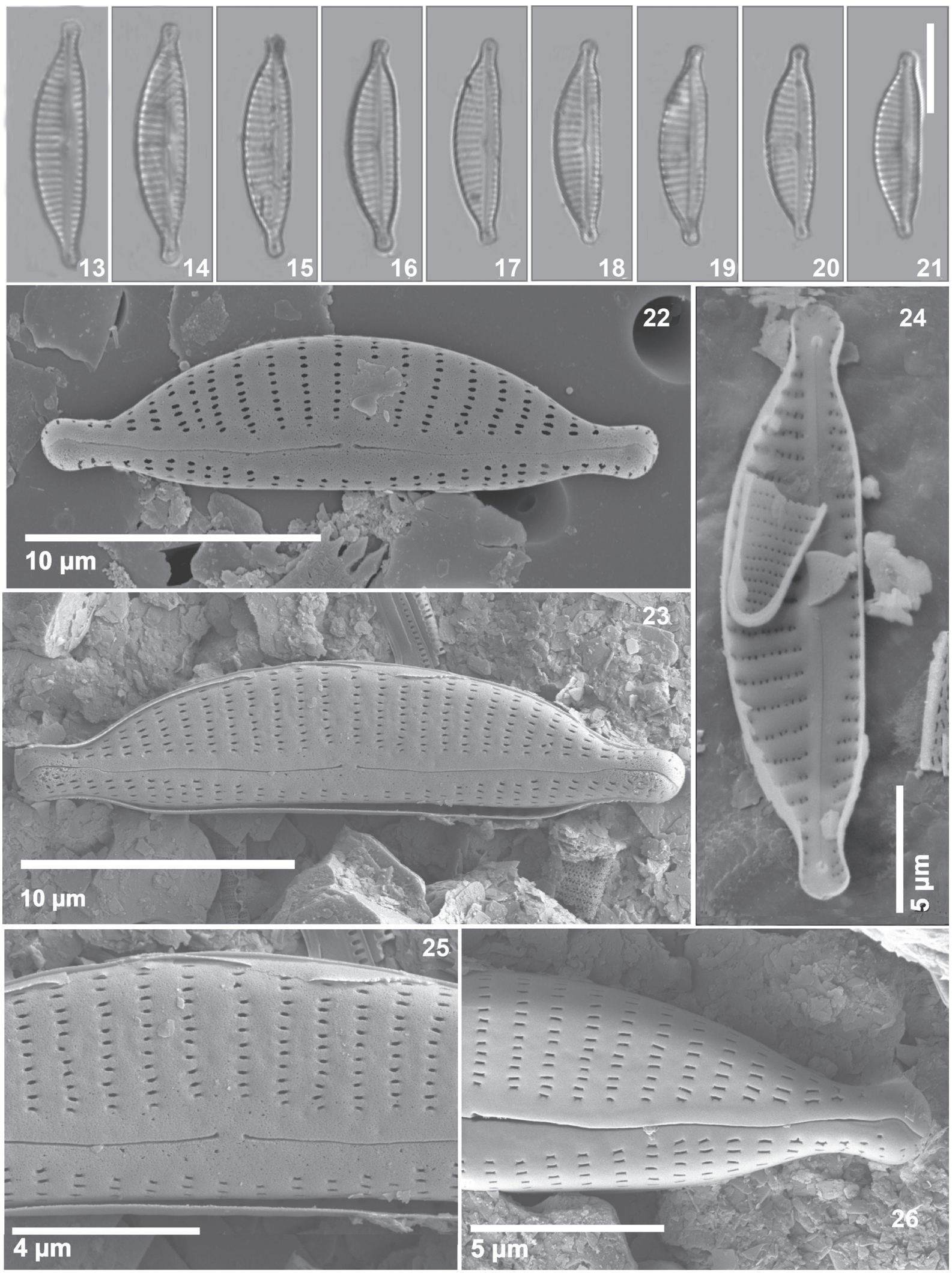

Figs 13-26. Encyonema acquapurae sp. nov., light and scanning electron micrographs, all pictures taken from the holotype population (SP401589): (13-21) LM views showing variation in size and valve outline; $(22,23,25,26)$ SEM external views of valve showing the raphe and striae structure; (24) SEM internal view of valve showing the raphe and striae structure, central area with intermissio. LM scale bar $10 \mu \mathrm{m}$ $(13-21)$. 
Table 3. NPMANOVA test performed on morphological differences resulting groups in the MDS using the Euclidean distance measure. $P$ values shown $(<0.001,<0.01,<0.05)$.

\begin{tabular}{llllll}
\hline & E. tenue & E. sparsistriatum & E. paradisiacum & E. angustecapitatum & E. ponteanum \\
\hline E. acquapurae & $<0.01$ & $<0.001$ & 0.002 & $<0.001$ & $<0.001$ \\
E. tenue & - & 0.0012 & $<0.05$ & $<0.001$ & $<0.01$ \\
E. sparsistriatum & - & $<0.001$ & $<0.05$ & $<0.01$ \\
E. paradisiacum & - & - & 0.0004 & $<0.001$ \\
E. angustecapitatum & & & - & 0.1593 \\
\hline
\end{tabular}

the ventral margin. Striae parallel to slightly radiate at the ends. Dorsal striae 11-12 in $10 \mu \mathrm{m}$, ventral striae $11-12$ in $10 \mu \mathrm{m}$. Indistinct areolae. Stigmoid absent.

Scanning electron microscopy (SEM) (Figs 48-51): External raphe fissure slightly undulate (Figs 48, 51). Proximal raphe end almost straight, the proximal endings are slightly curved to the dorsal side (Figs 48, 49, 51). Raphe distal ends first dorsally bent, and then strongly hooked to the ventral side (Figs 48, 51). Axial area is narrow, linear, and wider to the ventral side (Figs 48, 51). Striae composed of lineolate areolae along the valve irregularly arranged along the axial area (Figs 48,49$)$ numbering $45-50$ in $10 \mu \mathrm{m}$. Internally, the raphe fissure is interrupted by an intermissio (Fig. 50). Raphe distal endings terminating in well-developed helictoglossae (Fig. 50).

Etymology: The specific epithet refers to its more spaced and smaller striae number when compared to other species of the E. angustecapitatum complex.

Type locality: Brazil. São Paulo, Billings Reservoir, Rio Pequeno branch, sample SP401589 (2347'1.62"S, $\left.46^{\circ} 26^{\prime} 11.28^{\prime \prime} \mathrm{W}\right)$, leg. S. Wengrat et D. Bicudo, coll. date $06 / 08 / 2009$.

Holotype: SP401589 (Herbário Científico do Estado "Maria Eneyda P. Kauffmann Fidalgo", São Paulo, Brazil, depicted in Figs 39-47).

Isotype (here designated): BR-4422 (Botanic Garden, Meise, Belgium).

Taxonomic remarks: Encyonema sparsistriatum differs from E. acquapurae in its smaller dimensions (15.5-19.8 $\mu \mathrm{m}$ length and 4.0-4.5 $\mu \mathrm{m}$ width) and smaller striae density (11-12 in $10 \mu \mathrm{m})$ composed by rounded areolae, that also are more numerous (40-50) in a $10 \mu \mathrm{m}$ interval.

Encyonema sparsistriatum differs from Encyonema menezesiae W.J. SiLva et M.G.M. SouzA mainly in its valve outline and areolae shape: E. sparsistriatum is strongly dorsiventral and has rounded areolae, whereas E. menezesiae is slightly dorsiventral and has areolae with linear foramina.

Ecology: This new species was rare in the samples collected from the surface sediments of Billings reservoir
Rio Pequeno branch (relative abundance $\leq 2 \%$ ). The water is oligo-mesotrophic with low nutrient contents (Table 2). The new species was associated with Brachysira brebissonii, Encyonopsis sanctipaulensis, Encyonema angustecapitatum, Eunotia veneris and Encyonema acquapurae.

Encyonema paradisiacum MARQUARDT, Wengrat et C.E. Wetzel sp. nov. (Figs 52-66)

Light microscopy (LM) (Figs 52-60): Valves strongly dorsiventral. Dorsal side arched. Ventral margin slightly arched to linear. Apices narrow, rostrate, subcapitate to capitate. Length $18.3-26.8 \mu \mathrm{m}$. Width 3.2-3.8 $\mu \mathrm{m}$. Length to width ratio 5.3-7.2. Axial area narrow, linear, broader on the ventral margin. Central area absent. Raphe filiform, lateral. Proximal fissures weakly expanded, slightly curved to dorsal margin. Raphe distal ends strongly deflected to the ventral margin. Dorsal striae parallel to slightly radiate at the ends, dorsal striae $13-15$ in $10 \mu \mathrm{m}$, ventral striae $14-16$ in $10 \mu \mathrm{m}$, very short in the median area. Indistinct areolae. Stigmoid absent.

Scanning electron microscopy (SEM) (Figs 61-66): External raphe fissure slightly undulate (Fig. 61). Proximal end of raphe almost straight, slightly curved to the dorsal side (Figs 61, 62). Raphe distal ends are first dorsally bent, than strongly hooked to the ventral side (Figs 61, 62, 64). Axial area is narrow, linear, and wider to the ventral side (Figs 61, 62). Striae are composed of lineolate areolae, sometimes Y-shaped (Figs 61, 62, 64), numbering 35-40 in $10 \mu \mathrm{m}$. Internally, the raphe fissure is interrupted by an intermissio (Figs 63, 65). Raphe distal endings terminating in well-developed helictoglossae (Fig. 66).

Etymology: From Latin 'paradisus' or Greek 'paradeisos': paradise) in reference to the place where it was collected (Ribeirão do Campo reservoir).

Type locality: Brazil, São Paulo, Ribeirão do Campo Reservoir, sample SP427990 (23³9'31.8"S, 4549'23.22"W), A.C.R. Rocha et D.C. Bicudo, coll. date $13 / 08 / 2010$.

Holotype: SP468841 (Herbário Científico do Estado "Maria Eneyda P. Kauffmann Fidalgo", São Paulo, Brazil, depicted in Figs 52-60). 
Table 3. Main morphological characters of the new Encyonema species populations.

\begin{tabular}{|c|c|c|c|c|}
\hline & $\begin{array}{l}\text { Encyonema acqua- } \\
\text { purae }\end{array}$ & E. tenue & E. sparsistriatum & E. paradisiacum \\
\hline Valve outline & $\begin{array}{l}\text { dorsal side convex, } \\
\text { ventral side moderately } \\
\text { convex to straight }\end{array}$ & $\begin{array}{l}\text { dorsal side convex, } \\
\text { ventral side slightly } \\
\text { convex to straight }\end{array}$ & $\begin{array}{l}\text { dorsal side convex, } \\
\text { ventral side slightly } \\
\text { convex to straight }\end{array}$ & $\begin{array}{l}\text { dorsal side convex, } \\
\text { ventral side straight to } \\
\text { slightly convex }\end{array}$ \\
\hline Valve ends & $\begin{array}{l}\text { subcapitate to capitate, } \\
\text { sometimes deflected to } \\
\text { the ventral side }\end{array}$ & $\begin{array}{l}\text { capitate, sometimes } \\
\text { slightly deflected to } \\
\text { the ventral side }\end{array}$ & $\begin{array}{l}\text { rostrate to capitate, } \\
\text { sometimes deflected } \\
\text { to the ventral side }\end{array}$ & rostrate to subcapitate \\
\hline Length $(\mu \mathrm{m})$ & $20.8-27.4$ & $20.4-25.3$ & $15.5-21.5$ & $18.3-26.8$ \\
\hline Width $(\mu \mathrm{m})$ & $5.0-6.0$ & $4.0-4.5$ & $4.0-7$ & $3.2-3.8$ \\
\hline Striae arrangement & $\begin{array}{l}\text { parallel to slightly radi- } \\
\text { ate }\end{array}$ & $\begin{array}{l}\text { parallel to slightly } \\
\text { radiate }\end{array}$ & $\begin{array}{l}\text { parallel to slightly } \\
\text { radiate }\end{array}$ & $\begin{array}{l}\text { parallel to slightly } \\
\text { radiate }\end{array}$ \\
\hline $\begin{array}{l}\text { Maximum length to } \\
\text { width ratio }\end{array}$ & $4.0-4.7$ & $4.6-6.1$ & $4.0-4.8$ & $5.3-7.2$ \\
\hline Shoulder & clearly developed & clearly developed & poorly developed & absent \\
\hline Central area & absent & absent & absent & absent \\
\hline Axial area & narrow, ventral & $\begin{array}{l}\text { narrow, ventral or } \\
\text { sometimes dorsal }\end{array}$ & narrow, ventral & $\begin{array}{l}\text { narrow, ventral or } \\
\text { sometimes dorsal }\end{array}$ \\
\hline $\begin{array}{l}\text { Dorsal striae in } 10 \\
\mu \mathrm{m}\end{array}$ & $13-14$ & $11-14$ & $11-12$ & $13-15$ \\
\hline $\begin{array}{l}\text { Ventral striae in } 10 \\
\mu \mathrm{m}\end{array}$ & $13-16$ & $11-14$ & $11-12$ & $14-16$ \\
\hline Areolae in $10 \mu \mathrm{m}$ & 36 & $36-40$ & $40-50$ & $35-40$ \\
\hline $\begin{array}{l}\text { Morphology of the } \\
\text { areolae in external } \\
\text { view (SEM) }\end{array}$ & lineolate & rounded, lineolate & $\begin{array}{l}\text { lineolate, irregularly } \\
\text { arranged along axial } \\
\text { area }\end{array}$ & lineolate and $\mathrm{Y}$-shaped \\
\hline
\end{tabular}

Isotype (here designated): BR-4430 (Botanic Garden, Meise, Belgium).

Taxonomic remarks: Encyonema paradisiacum has strongly curved raphe to a very narrow ventral margin, with short striae placed only marginally or entirely absent. These features are similar to those of some Cymbellopsis KRAMMER species. However, according to KRAMMER (1997b) Encyonema structure significantly differs from Cymbellopsis. In the latter genus, the areolae are quite irregular and some of them often form clusters that appear as rough points at LM. Also, the foramina are either delicate apical elongated slots or irregularly $\mathrm{x}$-shaped openings. Regarding the areolae ultrastructure, SEM observations of E. paradisiacum showed that they are always lineolate or $\mathrm{Y}$-shaped (Figs 62, 63, 65) and their striae are not interrupted.
Ecology: The new species was somewhat rare in the surface sediments samples collected from Ribeirão do Campo reservoir (Salesópolis city, São Paulo state) (relative abundance $\leq 2 \%$ ). The water is oligotrophic with low nutrient contents (Table 2). The species was associated with Eunotia botuliformis F. WILD, NöRPEL et LANGe-Bertalot, E. bilunaris (EhrenBerg) SCHAARSCHMIDT and Brachysira serians (BRÉBISSON) Round et D.G. MANN.

\section{Morphological examination}

Differences between the studied groups were evidenced by using their morphological measurements (Fig. 1). Similarity tests (NPMANOVA) performed on the resulting groups in the MDS, revealed statistically significant differences ( $p$ values: $<0.001,<0.01,<0.05$ ) between the four studied taxa (Table 3) but not for $E$. 
angustecapitatum and for E. ponteanum. The small number of $E$. ponteanum representatives may have contributed to this result. However, no representative of the species was found during the re-examination of the type material, and the measures used in this analysis were based only on Krammer (1997b).

The procedure distinguished four groups of specimens as follows: E. acquapurae $(\mathrm{N}=15$ specimens), E. tenue $(\mathrm{N}=11$ specimens $)$, E. sparsistriatum $(\mathrm{N}=12$ specimens) and E. paradisiacum $(\mathrm{N}=15$ specimens $)$, besides $E$. angustecapitatum $(\mathrm{N}=7)$ and $E$. ponteanum $(\mathrm{N}=3)$ type materials (Fig. 4). These groups are evident during the ordination analysis, with a 'stress' of 0.07596 , indicating that graphical distances among species were close to the original similarities. All species were easily distinguished by the morphometric analysis approach (Fig. 2).

For the scatterplot matrix, correlation between length and width (0.45), length and length to width ratio $(0.57)$, width and length to width ratio $(-0.38)$, width and ventral striae $(0.27)$ and dorsal and ventral striae $(0.87)$ were significant and very useful features for species differentiation (Fig. 3).

\section{Final remarks and conclusion}

Present observations of the type material of E. angustecapitatum culminated with a better understanding of the complex identity, and helped to identify four new taxa that were formerly misidentified. The species in the E. angustecapitatum complex can be separated mainly by differences of their morphological features such as valve outline, axial area, valve length, valve width, length to width ratio, number of striae in $10 \mu \mathrm{m}$ and number and type of areolae in $10 \mu \mathrm{m}$. Although most morphological characteristics of the species examined are similar and overlap among themselves, analyses based on the combination of morphological data were useful for the identification of the E. angustecapitatum species complex. Morphometric and statistical analysis has been shown to be a useful and widely used tool for the separation of diatom complexes as well as to delimit important features in the species (e.g. WeN-
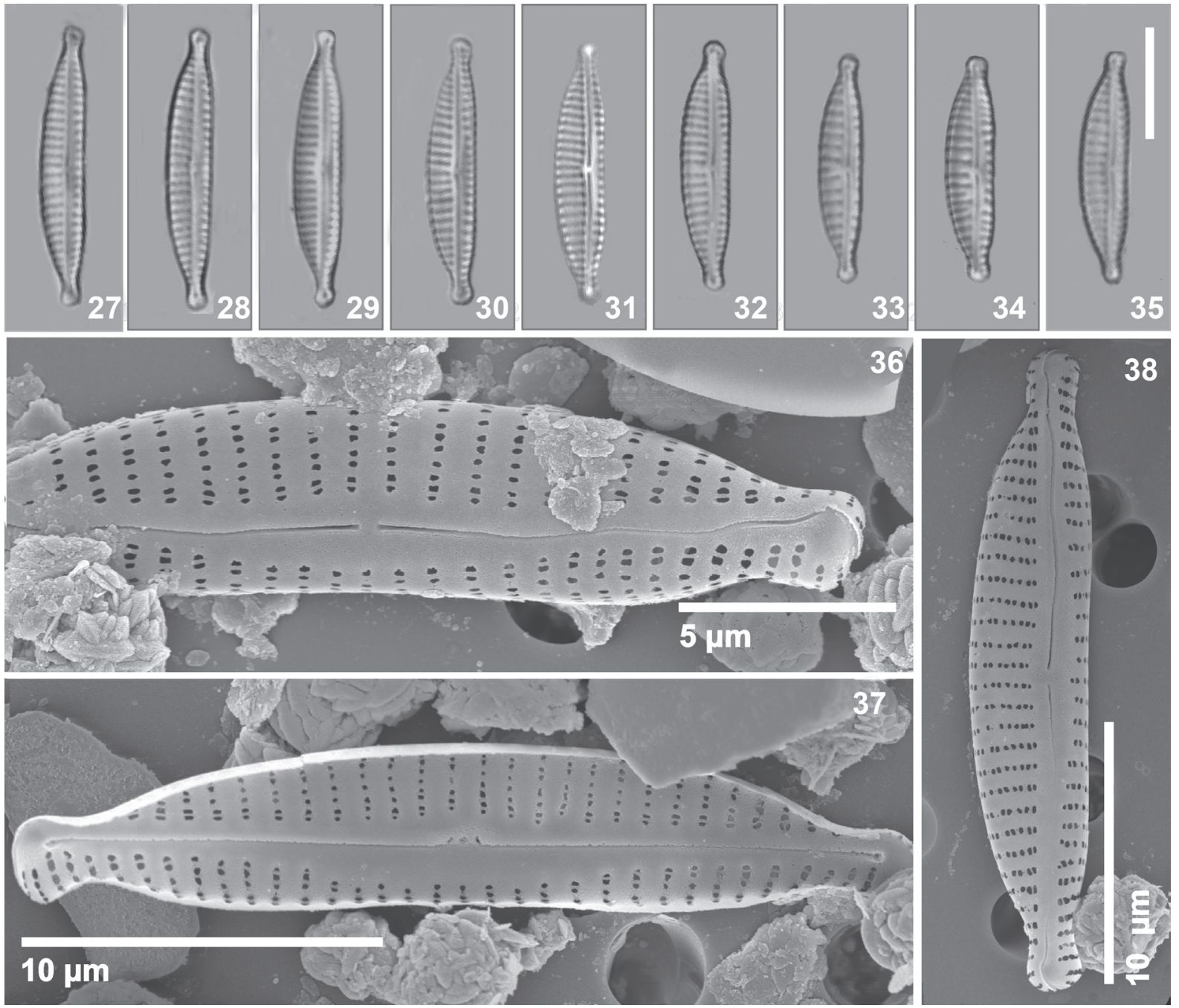

Figs 27-38. Encyonema tenue sp. nov., light and scanning electron micrographs, all pictures taken from the holotype population (SP188327): (27-35) LM views showing variation in size and valve outline; $(36,38)$ SEM external views of entire valve showing the raphe and striae structure; (37) SEM internal view of entire valve showing the raphe and striae structure, central area with intermissio. LM scale bar 10 $\mu \mathrm{m}$ (27-35). 
GRAT et al. 2015; WetZel \& Ector 2015; ŻELAZNAWIECZOREK \& OLSZYŃSKI 2016).

All species were quite rare in all samples currently studied making LM and SEM observations quite difficult. Their biogeography is still unclear, but just American's distribution were found until now (Fig. 67). We cannot excluded that the new species are more widespread than just in the São Paulo state. This observation concerns the significant amount of Cymbellales representatives recently described (e.g. BAHLs 2015; Le Cohu et al. 2015; Yana \& Mayama 2015; Heudre et al. 2016; MARquARDT et al. 2016). Moreover, the new taxa might be characteristic for oligotrophic habitats in tropical areas.

This study contributes to the need of documenting and illustrating diversity to facilitate research on diatom biogeography, ecology and paleoecology in Brazil. Further research on the diatom diversity of Brazilian environments may yet lead to the discovery of other new species due to the few taxonomic studies already performed and the little attention given to rare taxa.

\section{ACKNOWLEDGeMents}

We gratefully acknowledge Saúl Blanco for improving the manu- script. This study was carried out within the framework of BIOTA and AcquaSed projects financially supported by FAPESP (Fundação de Amparo à Pesquisa do Estado de São Paulo, BIOTA Project $\mathrm{n}^{\circ}$ 1998/04955-3 and AcquaSed Project $n^{\circ}$ 2009/53898-9); and was undertaken as part of GCM (FAPESP fellowship 2010/14658-0, 2013/10314-2) and SW (FAPESP fellowship 2012/25366-5 respectively) theses at the Instituto de Botânica, São Paulo, Brazil (FAPESP fellowship 2010/14658-0, 2013/10314-2 and 2012/25366-5 respectively). CEMB and DCB thanks CNPq (Conselho Nacional de Desenvolvimento Científico e Tecnológico) for Research Fellowships ( $\mathrm{n}^{\circ} 310940 / 2013-3$ and 303876/2004-2). This work has also benefited from the funding to the project DIATOMS (Luxembourg Institute of Science and Technology).

\section{REFERENCES}

BAHLS, L.L. (2015): Kurtkrammeria, a new genus of freshwater diatoms (Bacillariophyta, Cymbellaceae) separated from Encyonopsis. - Nova Hedwigia 101: $165-190$.

Battarbee, R.W.; Jones, V.J.; Flower, R.J.; Cameron, N.G.; Bennion, H.; Carvalho, L. \& Juggins, S. (2001): Diatoms. - In: SMOL, J.P.; BirKs, H.J.B. \& LAST, W.M. (eds): Tracking Environmental Change Using Lake Sediments. Volume 3: Terrestrial, Algal, and Siliceous Indicators. - pp. 155-202, Kluwer Academic Publishers, Dordrecht, Boston, London.
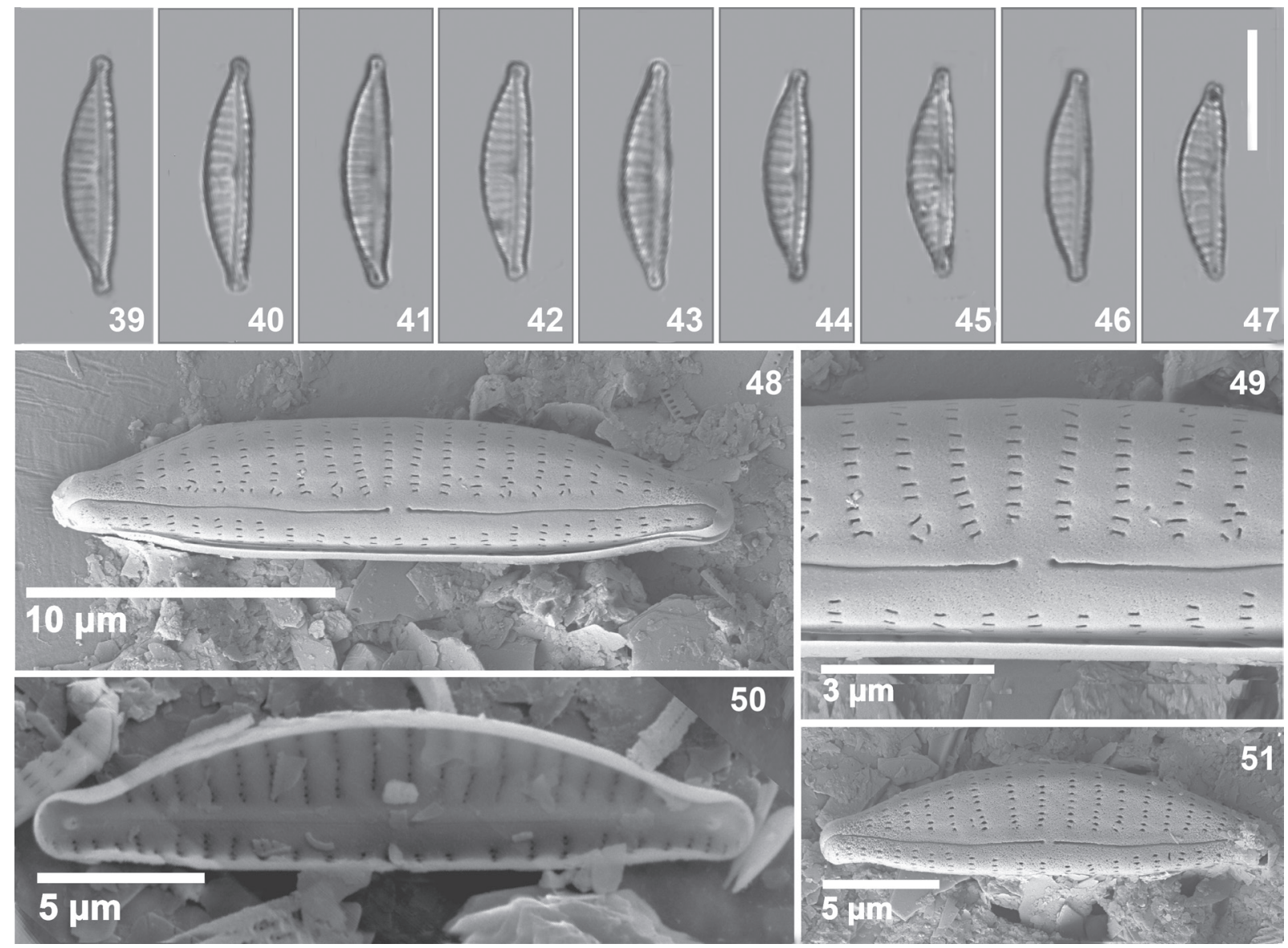

Figs 39-51. Encyonema sparsistriatum sp. nov., light and scanning electron micrographs, all pictures taken from the holotype population (SP401589): (39-47) LM views showing variation in size and valve outline; $(48,49,51)$ SEM external views of entire valve showing the raphe and striae structure; (50) SEM internal view of entire valve showing the raphe and striae structure. LM scale bar $10 \mu \mathrm{m}$ (Figs 39-47). 
Table 4. Main morphological characters of Encyonema angustecapitatum type materials and related species. nd: no data.

\begin{tabular}{|c|c|c|c|c|}
\hline & $\begin{array}{l}\text { Encyonema anguste- } \\
\text { capitatum } \\
\text { KRAMMER }\end{array}$ & $\begin{array}{l}\text { E. ponteanum } \\
\text { KRAMMER }\end{array}$ & $\begin{array}{l}\text { E. gaeumannii (F. } \\
\text { MEISTER) KRAM- } \\
\text { MER }\end{array}$ & $\begin{array}{l}\text { E. pankowii LANGE- } \\
\text { BERTALOT et KRAM- } \\
\text { MER in KRAMMER }\end{array}$ \\
\hline Valve outline & $\begin{array}{l}\text { dorsal side convex, } \\
\text { ventral side modera- } \\
\text { tely convex to straight }\end{array}$ & $\begin{array}{l}\text { strongly dorsiventral, } \\
\text { elliptic lanceolate, } \\
\text { dorsal side convex, } \\
\text { ventral side modera- } \\
\text { tely convex, straight } \\
\text { or slightly concave }\end{array}$ & $\begin{array}{l}\text { strongly dorsiven- } \\
\text { tral, elliptic lance- } \\
\text { olate }\end{array}$ & $\begin{array}{l}\text { strongly dorsiventral, } \\
\text { elliptic lanceolate, } \\
\text { dorsal side convex, } \\
\text { ventral side modera- } \\
\text { tely convex, straight } \\
\text { or slightly concave }\end{array}$ \\
\hline Valve ends & capitate & $\begin{array}{l}\text { capitate, narrow and } \\
\text { rounded }\end{array}$ & $\begin{array}{l}\text { capitate, broad and } \\
\text { rounded }\end{array}$ & $\begin{array}{l}\text { capitate, narrow and } \\
\text { rounded }\end{array}$ \\
\hline Length $(\mu \mathrm{m})$ & $17-24$ & $18-20$ & $14-22$ & $24-28$ \\
\hline Width $(\mu \mathrm{m})$ & $4.1-5.1$ & $3.8-4.2$ & $4-5$ & $5.5-6.5$ \\
\hline $\begin{array}{l}\text { Striae arrange- } \\
\text { ment }\end{array}$ & parallel & $\begin{array}{l}\text { parallel to slightly } \\
\text { radiate }\end{array}$ & $\begin{array}{l}\text { parallel to slightly } \\
\text { radiate }\end{array}$ & $\begin{array}{l}\text { parallel to slightly } \\
\text { radiate }\end{array}$ \\
\hline $\begin{array}{l}\text { Maximum length } \\
\text { to width ratio }\end{array}$ & 5.3 & 4.4 & 4.4 & 4.4 \\
\hline Shoulder & $\begin{array}{l}\text { rounded and clearly } \\
\text { developed }\end{array}$ & $\begin{array}{l}\text { clearly developed on } \\
\text { the ventral side }\end{array}$ & $\begin{array}{l}\text { sometimes absent } \\
\text { on the dorsal side }\end{array}$ & $\begin{array}{l}\text { clearly developed on } \\
\text { the ventral side }\end{array}$ \\
\hline Central area & $\begin{array}{l}\text { narrow, slightly ven- } \\
\text { tral }\end{array}$ & absent & $\begin{array}{l}\text { absent or slightly } \\
\text { dorsal }\end{array}$ & absent \\
\hline Axial area & narrow, linear & narrow, ventral & narrow, linear & narrow, ventral \\
\hline $\begin{array}{l}\text { Dorsal striae in } \\
10 \mu \mathrm{m}\end{array}$ & $12-15$ & $12-14$ & $15-18$ & $10-11$ \\
\hline $\begin{array}{l}\text { Ventral striae in } \\
10 \mu \mathrm{m}\end{array}$ & $14-15$ & $15-16$ & $18-19$ & $17-18$ \\
\hline $\begin{array}{l}\text { Areolae in } 10 \\
\mu \mathrm{m}\end{array}$ & $36-38$ & $28-32$ & $38-42$ & $18-20$ \\
\hline $\begin{array}{l}\text { Morphology of } \\
\text { the areolae in } \\
\text { external view } \\
\text { (SEM) }\end{array}$ & lineolate & nd & lineolate & nd \\
\hline
\end{tabular}

EskinaZi-LeÇA, E.; Moura, C.W.N.; Cunha, M.G.G.S.; SANTiago, M.F.; Borges, G.C.P.; Lima, J.C.; Silva, M.H.; Ferreira, L.C.; Aquino, E.; da Silva, W.J. \& MeneZES, M. (2015): Bacillariophyceae in Lista de Espécies da Flora do Brasil. Jardim Botânico do Rio de Janeiro. - Available in: $<$ http://floradobrasil.jbrj.gov. br/jabot/floradobrasil/FB98457>.

Fourtanier, E. \& Kociolek, J.P. (2011): Catalogue of Diatom Names, California Academy of Sciences, Online Version updated 19 Sep 2011. - Available from: http://researcharchive.calacademy.org/research/dia- toms/names/index.asp (accessed 30/08/16)

Fox, J. (2005): The R Commander: A basic-statistics graphical user interface to R. - Journal of Statistical Software 14: 1-42.

Fox, J. (2007): Extending the R Commander by "plug in" packages. - R News 7: 46-52.

Heudre, D.; Wetzel, C. E. \& Ector, L. (2016): Encyonema bonapartei sp. nov: a new freshwater diatom species (Cymbellales, Bacillariophyceae) in canals of Great East region (France). - Phytotaxa 284: 273-280.

Krammer, K. (1997a): Die cymbelloiden Diatomeen. Eine 


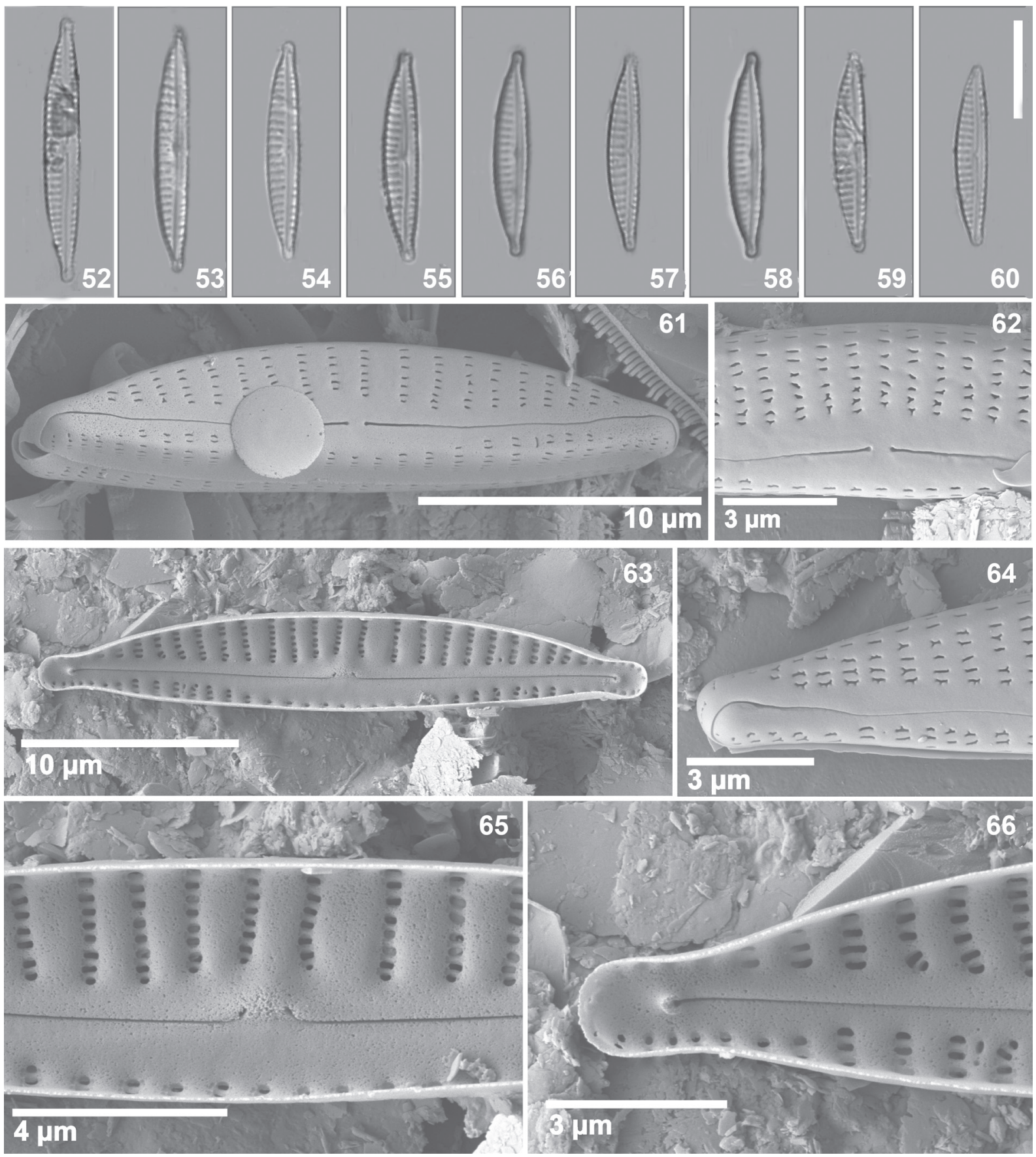

Figs 52-66. Encyonema paradisiacum sp. nov., light and scanning electron micrographs, all pictures taken from the holotype population (SP427990): (52-60) LM views showing variation in size and valve outline; $(61,62,64)$ SEM external views of entire valve showing the raphe and striae structure; $(63,65,66)$ SEM internal view of entire valve showing the raphe and striae structure; (65) detail of the intermissio. LM scale bar $10 \mu \mathrm{m}(52-60)$.

Monographie der weltweit bekannten Taxa. Teil 1. Allgemeines und Encyonema Part. - Bibliotheca Diatomologica 36: 1-382.

Krammer, K. (1997b): Die cymbelloiden Diatomeen. Eine Monographie der weltweit bekannten Taxa. Teil 2. Encyonema part., Encyonopsis and Cymbellopsis. Bibliotheca Diatomologica 37: 1-469.

Le Cohu, R.; Azémar, F. \& Tudesque, L. (2015): Cymbella marvanii sp. nov., a new Cymbella species from the French Pyrenees. - Diatom Research 30: 257-262.

Marquardt, G.C. \& Bicudo, C.E.M. (2014): Criptógamos do Parque Estadual das Fontes do Ipiranga, São Pau1o, SP. Algas 36: Bacillariophyceae (Cymbellales). Hoehnea 41: 209-246.

Marquardt, G.C.; Fürstenberger, C.B.; Chaouiche, T.E.; CAparica, R. \& CARApunarla, L. (2010): Diatomáceas (Bacillariophyceae) perifíticas em substratos naturais do rio das Pedras, município de Guarapuava, Paraná, Brasil. - Terra Plural 4: 217-240.

Marquardt, G.C.; Rocha, A.C.R.; Wetzel, C.E.; Ector, L. \& Bicudo, C.E.M. (2016): Encyonema aquasedis sp. nov. and Kurtkrammeria salesopolensis sp. nov.: 


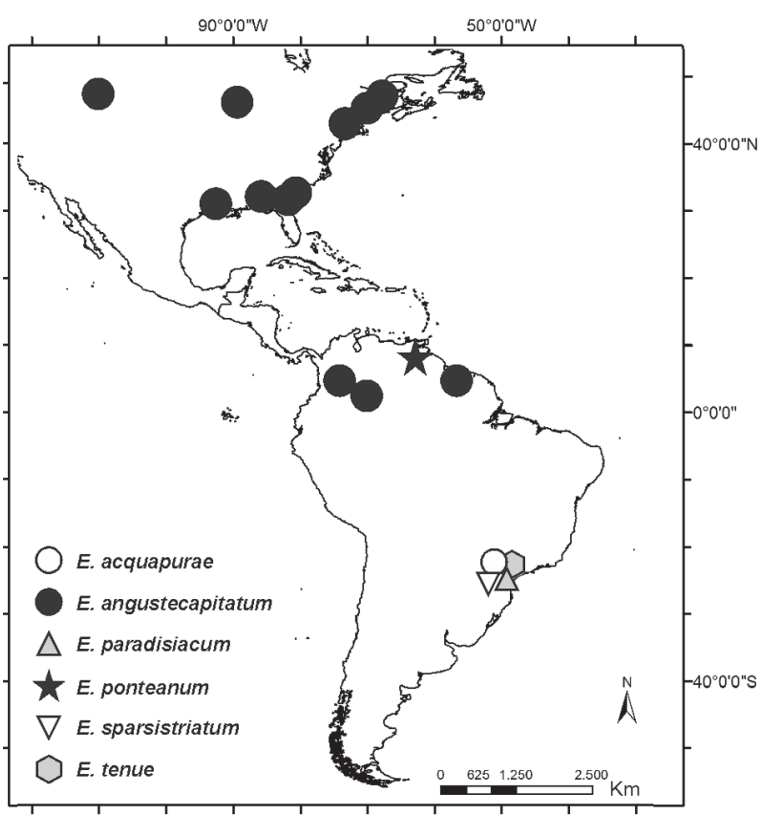

Fig. 67. Distribution of E. angustecapitatum complex reported from the literature: (black star) type locality of E. angustecapitatum and E. ponteanum in Venezuela; (white symbols) represent E. acquapurae distribution; (black symbol) represent E. angustecapitatum; (triangle) represent $E$. paradisiacum; (inverted triangle) represent $E$. sparsistriatum and (diamond) represent $E$. tenue.

two new freshwater diatom species (Cymbellales, Bacillariophyceae) from an oligotrophic reservoir in southeastern Brazil. - Phytotaxa 247: 62-74.

Metzeltin, D. \& Lange-Bertalot, H. (1998): Tropische Diatomeen in Südamerika I. 700 überwiegend wenig bekannte oder neue Taxa repräsentativ als Elemente der neotropischen Flora. - Iconographia Diatomologica 5: 1-695.

Montoya-Moreno, Y.; Sala, S.; Vouilloud, A.; Aguirre, N. \& Plata, Y. (2013): Lista de las diatomeas de ambientes continentales de Colombia. - Biota Colombiana 14: 13-78.

Oksanen, J.F.; Blanchet, G.; Kindt, R.; Legendre, P.; MinCHIN, P.R.; O'Hara, R.B.; Simpson, G.L.; Solymos, P.; Henry, M.H. \& Stevens, W.H. (2016): Vegan: Community Ecology Package. R package version 2.3-5. - Available online at https://CRAN.R-project.org/ package $=$ vegan

Peterson, B.G.; Carl, P.; Boudt, K.; Bennett, R. \& Ulrich, J. (2014): Performance Analytics: Econometric tools for performance and risk analysis. $\mathrm{R}$ package version.

Pomazkina, G.V. \& Rodionova, E.V. (2014): Diatoms of the family Cymbellaceae of Lake Baikal. Atlas and key. -242 pp, NAUKA, Novosibirsk.

R Development Core Team (2015): R: A language and environment for statistical computing. R Foundation for Statistical Computing, Vienna, Austria. - Available online at http://www.R-project.org/.

Round, F.E.; Crawford, R.M. \& Mann, D.G. (1990): The diatoms: biology \& morphology of the genera. - 747 pp, Cambridge University Press, Cambridge.

Rumrich, U.; Lange-Bertalot, H. \& Rumrich, M. (2000): Diatomeen der Anden. Von Venezuela bis Patagonien/Feuerland. - Iconographia Diatomologica 9:
$1-649$.

Silva, W.J. \& Souza, M.G.M. (2015): New species of the genus Encyonema (Cymbellales, Bacillariophyta) from the Descoberto River Basin, Central-western Brazil. - Phytotaxa 195: 154-162.

Silva, W.J.; Jahn, R.; Ludwig, T.A.V. \& Menezes, M. (2013a): Typification of seven species of Encyonema and characterization of Encyonema leibleinii comb. nov. - Fottea 13: 119-132.

Silva, W.J.; Souza, M.G.M. \& ProençA, C.E.B. (2013b): Cymbella neolanceolata sp. nov., a species formerly known as Cymbella lanceolata. - Diatom Research 28: 131-138.

Souza, M.G.M. \& Oliveira, R.I.R. (2007): 3.3 - Levantamento da diatomoflórula epilítica da bacia do rio Paranã, Goiás, Brasil. - In: MARTins-SiLva, M.J. (Org.): Inventário da biota aquática com vistas a conservação e utilização sustentável do bioma Cerrado (Serra e Vale do rio Paranã). - pp. 72-92, Brasília, Ministério do Meio Ambiente.

Tremarin, P.I.; Wetzel, C.E.; Ludwig, T.A.V. \& Ector, L. (2011): Encyonema exuberans sp. nov. (Bacillariophyceae) from southern Brazilian lotic systems. Nova Hedwigia 92: 107-120.

VAN DoRn, W.G. (1956): Large-volume water-samplers. - Transactions, American Geophysical Union 37: 682-684.

Vouilloud, A.A.; Sala, S.E.; Avellaneda, M.N. \& Duque, S.R. (2010): Diatoms from the Colombian and Peruvian Amazon: the genera Encyonema, Encyonopsis and Gomphonema (Cymbellales: Bacillariophyceae). - Revista de Biologia Tropical 58: 45-62.

Wengrat, S.; Marquardt, G.C.; Bicudo, D.C.; Bicudo, C.E.M.; Wetzel, C.E. \& Ector, L. (2015): Type analysis of Cymbella schubartii and two new Encyonopsis species (Bacillariophyceae) from southeastern Brazil. - Phytotaxa 221: 247-264.

Wetzel, C.E. \& Ector, L. (2015): Taxonomy and ecology of Fragilaria microvaucheriae sp. nov. and comparison with the type materials of $F$. uliginosa and $F$. vaucheriae. - Cryptogamie, Algologie 36: 271-289.

Yana, E. \& Mayama, S. (2015): Two new taxa of Achnanthidium and Encyonema (Bacillariophyceae) from the Yom River, Thailand, with special reference to the areolae occlusions implying ontogenetic relationship. - Phycological Research 63: 239-252.

Żelazna-WieczoreK, J. \& OlszyŃski, R. (2016): Taxonomic revision of Chamaepinnularia krookiformis LangeBertalot et Krammer with a description of Chamaepinnularia plinskii sp. nov. - Fottea 16: 112-121.

(C) Czech Phycological Society (2017)

Received December 15, 2016

Accepted March 7, 2017 